\title{
Crassostrea gigas oysters as a shrimp farm bioindicator of white spot syndrome virus
}

\author{
C. Vazquez-Boucard ${ }^{1, *}$, C. Escobedo-Fregoso ${ }^{1}$, Ma. de J. Duran-Avelar ${ }^{2}$, \\ L. Mercier ${ }^{1}$, R. Llera-Herrera ${ }^{1}$, C. Escobedo-Bonilla ${ }^{3}$, N. Vibanco-Perez ${ }^{2}$ \\ ${ }^{1}$ Biomedicine, Biochemistry and Molecular Laboratory, Centro de Investigaciones Biológicas del Noroeste, La Paz 23090, \\ Baja California Sur, Mexico \\ ${ }^{2}$ Universidad Autónoma de Nayarit, Tepic 63155, Nayarit, Mexico \\ ${ }^{3}$ Centro Interdisciplinario de Investigación para el Desarrollo Integral Regional, IPN, Guasave 81101, Sinaloa, Mexico
}

\begin{abstract}
This study explored whether Crassostrea gigas oysters can be used as a bioindicator of white spot syndrome virus (WSSV) in shrimp farm water canals. Bioassays showed that C. gigas can accumulate WSSV in their gills and digestive glands but do not become infected, either by exposure to seawater containing WSSV or by cohabitation with infected shrimp. The use of a WSSV nested PCR to screen oysters placed in water canals at the entry of a shrimp farm allowed WSSV to be detected $16 \mathrm{~d}$ prior to the disease occurring. The finding that $C$. gigas can concentrate small amounts of WSSV present in seawater without being harmed makes it an ideal sentinel species at shrimp farms.
\end{abstract}

KEY WORDS: WSSV $\cdot$ Disease management $\cdot$ Bivalve $\cdot$ Sentinel species

Resale or republication not permitted without written consent of the publisher

\section{INTRODUCTION}

In Mexico, shrimp farming is the most economically important aquaculture sector with production exceeding 130000 t in 2009 (Comisión Nacional de Acuacultura y Pesca 2009). However, this industry is plagued by white spot syndrome virus (WSSV) which causes a high number of mortalities and substantial economic losses. WSSV has a wide host range including salt and brackish water shrimp species as well as crabs, lobsters, crayfish and freshwater shrimp (Chang et al. 1998, Rajendran et al. 1999, Chen et al. 2000, Huang et al. 2001, Hameed et al. 2003). There is no clear understanding of the mechanisms that lead to epizootic events, and routine water analyses provide shrimp farmers with no information on the presence of WSSV to initiate measures to restrict its impact. In aquaculture ponds, infection can lead to $100 \%$ shrimp mortality within 3 to $10 \mathrm{~d}$ after the appearance of the first clinical signs of white spot disease (WSD) (EscobedoBonilla et al. 2008) and currently there are no effective treatments. Once WSSV enters a pond, it can spread rapidly and uncontrollably (Sánchez-Martínez et al. 2007). Thus the only means of minimizing the impact of WSD is to restrict or reduce virus entry into ponds (Sritunyalucksana et al. 2006). Waterborne transmission of WSSV infection is an important disease factor in both natural and culture environments (Chou et al. 1998, Wu et al. 2001, Corsin et al. 2005), and virus particles have recently been shown to be able to associate with various micro-, nano- and picoplankton species (Esparza-Leal et al. 2009).

As filter-feeding sedentary organisms, bivalve molluscs can retain and/or accumulate virus particles from food or water in their gills and digestive system (Sobsey \& Jaykus 1991). Because of this, they have long been used as environmental biomonitors to detect waterborne chemicals and metals (Claisse 1989, Kwan et al. 2003), as well as bacteria, parasites and viruses impacting humans (Miller et al. 2005). Previously, we reported the presence of WSSV in the gills and digestive glands of Crassostrea gigas oys- 
ters placed in water supply canals at a farm where a WSD outbreak had occurred (Vazquez-Boucard et al. 2010). Here, oysters were investigated for their potential use as an early warning bioindicator of WSSV in shrimp farm water inlets. Before examining the use of C. gigas oysters at a local shrimp farm, laboratory bioassays were performed to confirm their ability to accumulate WSSV and insusceptibility to infection and disease.

\section{MATERIALS AND METHODS}

\section{Virus inoculum}

Abdominal tissue of WSSV-infected Litopenaeus vannamei shrimp was homogenized with phosphatebuffered saline (PBS, pH 7.4, 1:10 v/v) and clarified at $3500 \times g$ for $20 \mathrm{~min}$ at $4^{\circ} \mathrm{C}$. The supernatant was transferred to a clean tube and clarified further at $13000 \times$ $g$ for $20 \mathrm{~min}$ at $4^{\circ} \mathrm{C}$. This highly clarified supernatant was then filtered through a $0.2 \mu \mathrm{m}$ membrane filter and serial 10-fold dilutions $\left(10^{-2}, 10^{-3}, 10^{-4}, 10^{-5}, 10^{-6}\right.$ and $\left.10^{-7}\right)$ were prepared in PBS. Aliquots $(50 \mu \mathrm{l})$ of each dilution were injected into tail muscle of $5 \mathrm{~L}$. vannamei weighing $40 \pm 4 \mathrm{~g}$ (mean $\pm \mathrm{SE}$ ). Prior to inoculation, haemolymph collected from several shrimp was tested by PCR to confirm the absence of WSSV infection. Individual shrimp were held in $10 \mathrm{l}$ tanks containing aerated seawater at $27 \pm 1^{\circ} \mathrm{C}$ and $35 \mathrm{~g} \mathrm{l}^{-1}$ salinity and observed every $12 \mathrm{~h}$; any dead or moribund shrimp were removed and frozen at $-80^{\circ} \mathrm{C}$. At Day 5 post-injection (p.i.), muscle tissue from all stored moribund and dead shrimp was tested for WSSV using a nested PCR. The virus infection dose $50 \%$ endpoint $\left(\mathrm{ID}_{50}\right)$ was calculated using the method of Reed \& Muench (1938), as adapted by EscobedoBonilla et al. (2005) for WSSV in Litopenaeus vannamei, and was expressed per ml of filtrate. Briefly, the percent mortality $(M)$ was determined at each inoculum dilution and the proportional distance (50\% $\left.M_{\mathrm{b}}\right) /\left(M_{\mathrm{a}}-M_{\mathrm{b}}\right)$ was calculated using the mortalities at the dilutions directly above (a) and below (b) the $50 \%$ mortality point. The proportional distance was then added to the $\log _{10}$ of Dilution $b$ in order to derive $\mathrm{ID}_{50} \mathrm{ml}^{-1}$ for the inoculum following correction for the injection of a $50 \mu \mathrm{l}$ volume.

\section{Infection bioassays}

To determine whether Crassostrea gigas is susceptible to WSSV infection, (1) WSSV-free oysters and
Litopenaeus vannamei were immersed in water to which WSSV inoculum had been added and (2) WSSV-free oysters were placed in tanks containing WSSV-infected L. vannamei. Shrimp were obtained from a hatchery located in Sinaloa, Mexico, and oysters were obtained from a farm on the Pacific coast of the state of Baja California Sur, Mexico, a region free of WSSV. Bioassays were carried out at the Centro Interdisciplinario de Investigación para el Desarrollo Integral Regional in Sinaloa. WSSV inoculum doses of 30 and 4 ID $_{50}$ were used. According to EscobedoBonilla et al. (2006), 30 ID $_{50}$ is considered a standard dose to infect shrimp by intramuscular and oral routes. Thus, $4 \mathrm{ID}_{50}$ was estimated to be a low infectious dose.

\section{Bioassay 1}

WSSV-free Crassostrea gigas ( $\mathrm{n}=27$ ) measuring $13 \pm 2 \mathrm{~cm}$ in diameter were acclimated to laboratory tank conditions for $1 \mathrm{mo}$ and then divided into 3 tanks (12 1 each) filled with artificial seawater (salinity $35 \mathrm{~g}$ $\mathrm{l}^{-1}$ ) at $28 \pm 2^{\circ} \mathrm{C}$. WSSV inoculum $\left(4 \mathrm{ID}_{50}\right)$ was added to the water of Tanks 1 and 2 but not Tank 3. In another tank, 12 Litopenaeus vannamei weighing $2 \pm 0.1 \mathrm{~g}$ were immersed in water containing WSSV inoculum $\left(4 \mathrm{ID}_{50}\right)$. Oysters and shrimp were fed Isochrysis galbana at the beginning of the trial and every $24 \mathrm{~h}$ thereafter. At 24, 48 and 72 h, 3 oysters were collected from each tank, from which gill and digestive gland tissue were extracted and then preserved in $70 \%$ ethanol for PCR analysis. Additional gill fragments were fixed in either $10 \%$ formaldehyde or Davidson's solution for in situ hybridization and histology, respectively. At the end of the trial, muscle from all shrimp was collected and preserved in $70 \%$ ethanol.

Bioassay 2

Litopenaeus vannamei ( $\mathrm{n}=6$ per tank; $40 \pm 3 \mathrm{~g}$ ) were injected intramuscularly with $50 \mu \mathrm{l}$ WSSV at a dose of $30 \mathrm{ID}_{50}$ and placed in 3 tanks employing the same water conditions as used in Bioassay 1. WSSVfree Crassostrea gigas ( $\mathrm{n}=9$ per tank) were placed into 2 of the 3 tanks containing $L$. vannamei injected with WSSV. Dead shrimp were collected every $12 \mathrm{~h}$ and muscle tissue was preserved in $70 \%$ ethanol. Gill and digestive gland tissue were collected from 2 oysters sampled from each tank at 24, 36, 48 and $60 \mathrm{~h}$ and from the remaining oyster in each tank at $72 \mathrm{~h}$, all of which were preserved in $70 \%$ ethanol. 


\section{Oyster sentinel system for WSSV at a shrimp farm}

WSSV-free Crassostrea gigas oysters obtained from a farm in Baja California Sur State were transported to Centro de Investigaciones Biológicas del Noroeste (CIBNOR). Immediately upon arrival, oysters were rinsed and depurated over a $10 \mathrm{~d}$ period in tanks supplied continuously with filtered seawater. The oysters were then relocated to a water supply canal at a shrimp farm located in El Dorado, Sinaloa, Mexico, where WSD outbreaks occur frequently. Oysters ( $\mathrm{n}=$ 720) were housed inside 3 modules of 3 plastic boxes containing 80 individuals each. Oysters $(n=20)$ were sampled randomly from the 3 modules every $2 \mathrm{~d}$ beginning on Day 6 after submersion in the water supply canal. Oysters were sampled 28 times between 23 March and 25 May 2010 and were transported frozen at $-20^{\circ} \mathrm{C}$ to $\mathrm{CIBNOR}$ and the Universidad Autónoma de Nayarit for WSSV nested PCR analysis. One oyster stored upon receipt at CIBNOR and another stored prior to being relocated to the shrimp farm at Sinaloa were used as nested PCR negative controls.

\section{WSSV nested PCR}

Total DNA was extracted using the commercial GeneClean II Kit (QBiogene) and amplified by PCR and then a nested PCR using primers described previously (Kimura et al. 1996). Briefly, each PCR (25 $\mu \mathrm{l})$ contained $0.2 \mathrm{mM}$ dNTP mixture, $2 \mathrm{mM} \mathrm{MgCl}_{2}$, 0.4 pmol of each WSSV out-1/out-2 primer, $1.25 \mathrm{U}$ Taq DNA polymerase (Invitrogen) and $100 \mathrm{ng}$ DNA. Nested PCR used the same reaction conditions except for the use of the nested primers WSSV in-1/ in- 2 and $1 \mu \mathrm{l}$ PCR as template. Thermal cycling conditions for both PCRs were $95^{\circ} \mathrm{C}$ for $4 \mathrm{~min}, 35$ cycles of $95^{\circ} \mathrm{C}$ for $30 \mathrm{~s}, 55^{\circ} \mathrm{C}$ for $30 \mathrm{~s}$, and $72^{\circ} \mathrm{C}$ for $90 \mathrm{~s}$, followed by $72^{\circ} \mathrm{C}$ for $5 \mathrm{~min}$. Each PCR batch included a known WSSV-positive DNA and sterile water as a negative control. Amplicon sizes expected in the PCR and nested PCR were $982 \mathrm{bp}$ and $570 \mathrm{bp}$, respectively. An aliquot of each nested PCR was subjected to a $1 \%$ agarose gel electrophoresis containing ethidium bromide and DNA bands were visualized using a UV transilluminator and photographed. Some nested PCR products were sequenced.

\section{Histology}

Histology was performed using standard methods (Lightner 1996). Gill tissue of Crassostrea gigas was sectioned into 3-5 $\mu \mathrm{m}$ slices, mounted onto glass slides and stained using haematoxylin and eosin (H\&E) (Luna 1968). As described in other crustaceans (Unzueta Bustamante et al. 2004), the presence of prominent eosinophilic inclusion bodies in hypertrophied nuclei of cells was used as a WSSV-infection criterion.

\section{In situ hybridization}

Crassostrea gigas gill tissue was analyzed for WSSV DNA using an in situ hybridization (ISH) method described previously (Le Roux et al. 1999). A digoxigenin (DIG)-labeled WSSV DNA probe was prepared by labeling a 570 bp nested PCR product using random primers and digoxigenindUTP as described in the instructions for a DIG DNA Labeling and Detection Kit (Roche Molecular Biochemicals). Tissue sections mounted on polyprep slides (Sigma-Aldrich) were deparaffinized with xylene, rehydrated through a graded series of alcohol concentrations, immersed in PBS pH 7.3 and incubated at $37^{\circ} \mathrm{C}$ for $15 \mathrm{~min}$ in $\mathrm{PBS}$ containing $10 \mu \mathrm{g} \mathrm{ml}^{-1}$ Proteinase K. After washing twice in PBS, tissue was immersed under $100 \mu \mathrm{l}$ hybridization solution (DIG DNA Kit locking solution in 0.1 M maleic acid, 0.15 $\mathrm{M} \mathrm{NaCl}, \mathrm{pH} 7.5$ ) containing $3 \mu \mathrm{l}$ probe and incubated at $42^{\circ} \mathrm{C}$ overnight in a humidity chamber. After washes the slides were observed under a light microscope (Leica Olympus BX41).

\section{RESULTS}

\section{Titration of the WSSV inoculum}

Amongst groups of Litopenaeus vannamei shrimp injected with serial 10-fold dilutions of WSSV inoculum, lethargy and abnormal swimming, typical of early signs of WSD, were observed at $48 \mathrm{~h}$ p.i. in shrimp injected at the highest dose $\left(10^{-2}\right.$ dilution). At $60 \mathrm{~h}$ p.i., all shrimp injected with $10^{-2}$ and $10^{-3}$ inoculum dilutions had died, and by Day 5 p.i. $80 \%$ of the shrimp injected with the $10^{-4}$ dilution had died. PCR analysis confirmed the presence of WSSV DNA in the muscle tissue of shrimp that died. Shrimp injected with $10^{-5}, 10^{-6}$ and $10^{-7}$ inoculum dilutions showed no signs of infection. Based on the bioassay data, the WSSV inoculum infectious dose $50 \%$ endpoint was calculated to be $10^{5.7} \mathrm{ID}_{50} \mathrm{ml}^{-1}$. 


\section{Exposure of oysters to waterborne WSSV (Bioassay 1)}

Amongst Crassostrea gigas oysters immersed in sea water containing $4 \mathrm{ID}_{50} \mathrm{ml}^{-1}$ of WSSV inoculum for $72 \mathrm{~h}$, WSSV DNA was detected by nested PCR in gills of $7(39 \%)$ of the 18 oysters and in digestive glands of $8(44 \%)$ of the same 18 oysters (Fig. 1). In only 2 oysters was WSSV DNA detected in both gill and digestive gland tissue and none displayed any clinical signs of being infected. The gills and digestive glands of all 9 oysters not exposed to WSSV tested negative by PCR (data not shown). None of the Litopenaeus vannamei shrimp exposed to the same dose of WSSV died or displayed clinical signs of WSD and no WSSV DNA was detected in muscle tissue by nested PCR (data not shown).
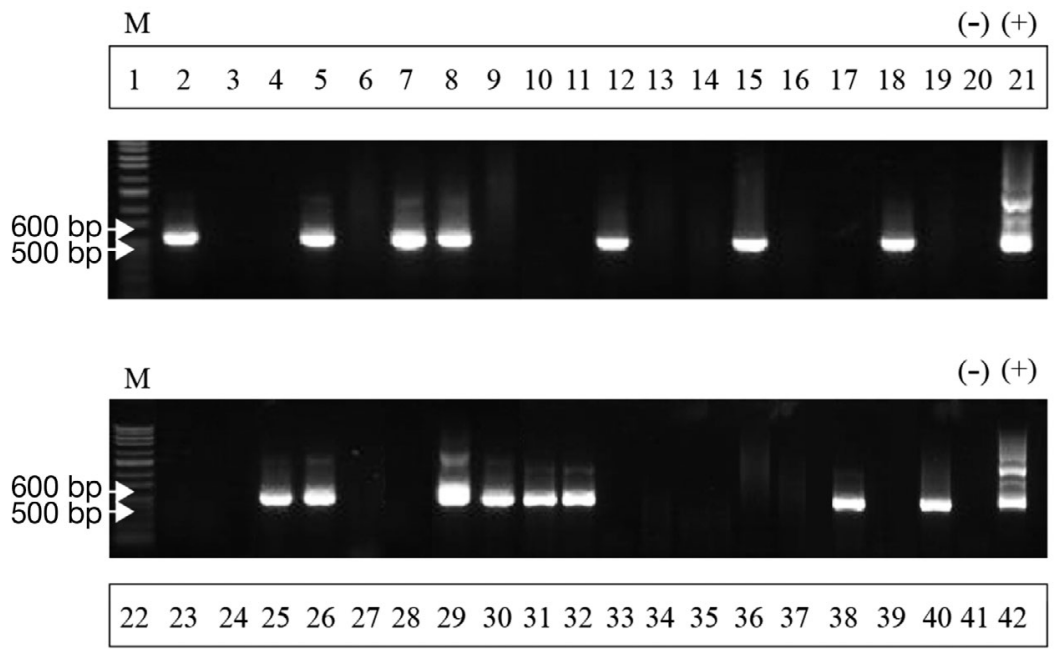

Fig. 1. Crassostrea gigas. Agarose gel showing the white spot syndrome virus (WSSV) nested PCR product amplified from oysters immersed in seawater containing $4 \mathrm{ID}_{50} \mathrm{ml}^{-1}$ WSSV inoculum (Bioassay 1). Lanes 1, 22: DNA size markers; Lanes 2-19: gill DNA from 18 oysters; Lanes 23-40: digestive gland DNA from the same oysters; Lanes 21, 42: WSSV DNA positive control; Lanes 20, 41: negative controls (water)

Table 1. Crassostrea gigas. Gill and digestive gland tissues of oysters that tested positive by nested PCR out of the total number of oysters sampled for white spot syndrome virus after being placed in a water supply canal at a shrimp farm situated in El Dorado, Sinaloa, Mexico, in 2010. Groups of 20 oysters were sampled every second day during the sampling dates shown

\begin{tabular}{|lccccc|}
\hline \multirow{2}{*}{ Tissue type } & \multicolumn{5}{c|}{ Sampling dates } \\
\cline { 2 - 6 } & \multirow{2}{*}{ 21-30 Mar } & 3 Apr & 6 Apr & 8 Apr & 11 Apr-25 May \\
\hline \multirow{2}{*}{ Gill } & $0 / 100$ & $1 / 20$ & $6 / 20$ & $11 / 20$ & $0 / 380$ \\
Digestive gland & $0 / 100$ & $2 / 20$ & $0 / 20$ & $0 / 20$ & $0 / 380$ \\
\hline
\end{tabular}

\section{(Bioassay 2)}

Amongst the Crassostrea gigas oysters cohabitating with WSSV-infected Litopenaeus vannamei shrimp and sampled progressively over a $3 \mathrm{~d}$ period, WSSV DNA was detected by nested PCR in gills of 4 $22 \%)$ of 18 oysters and in digestive glands of 3 $17 \%)$ of these same 18 oysters. All the shrimp had died by $60 \mathrm{~h}$ p.i. and all tested positive for WSSV by nested PCR.

\section{WSSV detection in sentinel oysters placed at a shrimp farm}

Crassostrea gigas oysters were placed in a water intake canal at a Litopenaeus vannamei shrimp farm in a region of Mexico prone to WSD outbreaks. Among groups of 20 oysters sampled randomly on 28 occasions over a $54 \mathrm{~d}$ period between 23 March and 25 May 2010, only oysters sampled on 3, 6 and 8 April were found to be positive for WSSV by nested PCR at prevalence rates of 15 , 20 and $55 \%$, respectively (Table 1 ). Sequence analysis of the $485 \mathrm{bp}$ nested PCR products showed $99 \%$ nucleotide identity with WSSV types originating from shrimp farmed in Thailand (GenBank AF369029), China (GenBank NC003225) and Taiwan (GenBank AF440570) as well as with a WSSV type detected in plankton collected from a shrimp farm in Guasave Sinaloa (GenBank FJ609650) and in shrimp sampled previously from the same study region (GenBank FJ789570; Peinado-Guevara \& LópezMeyer 2006). During the study period on 19 April, a WSD outbreak causing $\sim 50 \%$ shrimp mortality occurred at the farm being studied (J. Cabanillas, Comité de Sanidad Acuícola de Sinaloa pers. comm.).

\section{Histology and in situ hybridization (ISH)}

Histology on gills of Crassostrea gigas oysters exposed to water con- 
taining WSSV (Bioassay 1) for $3 \mathrm{~d}$ found no evidence of hypertrophied cell nuclei or WSSV inclusion bodies. However, high levels of ISH signal were evident in gills of oysters also found to be positive for WSSV by nested PCR (Fig. 2). The ISH signal was localized to the lumen of the gills rather than occurring at intracellular locations. No ISH signal was detected amongst exposed oysters that tested negative by nested PCR or amongst non-exposed control oysters (data not shown).

\section{DISCUSSION}

Due to bivalve molluscs being sedentary filterfeeders, they have been used effectively as aquatic bioindicators of waterborne fecal bacteria and viruses of human concern (Miller et al. 2005, Neira et al. 2010). This study validated the potential usefulness of Crassostrea gigas oysters as sentinels for detecting entry of waterborne WSSV into shrimp farms in Mexico. WSSV accumulated in oyster gills as it did in transmission trials, and demonstrated that
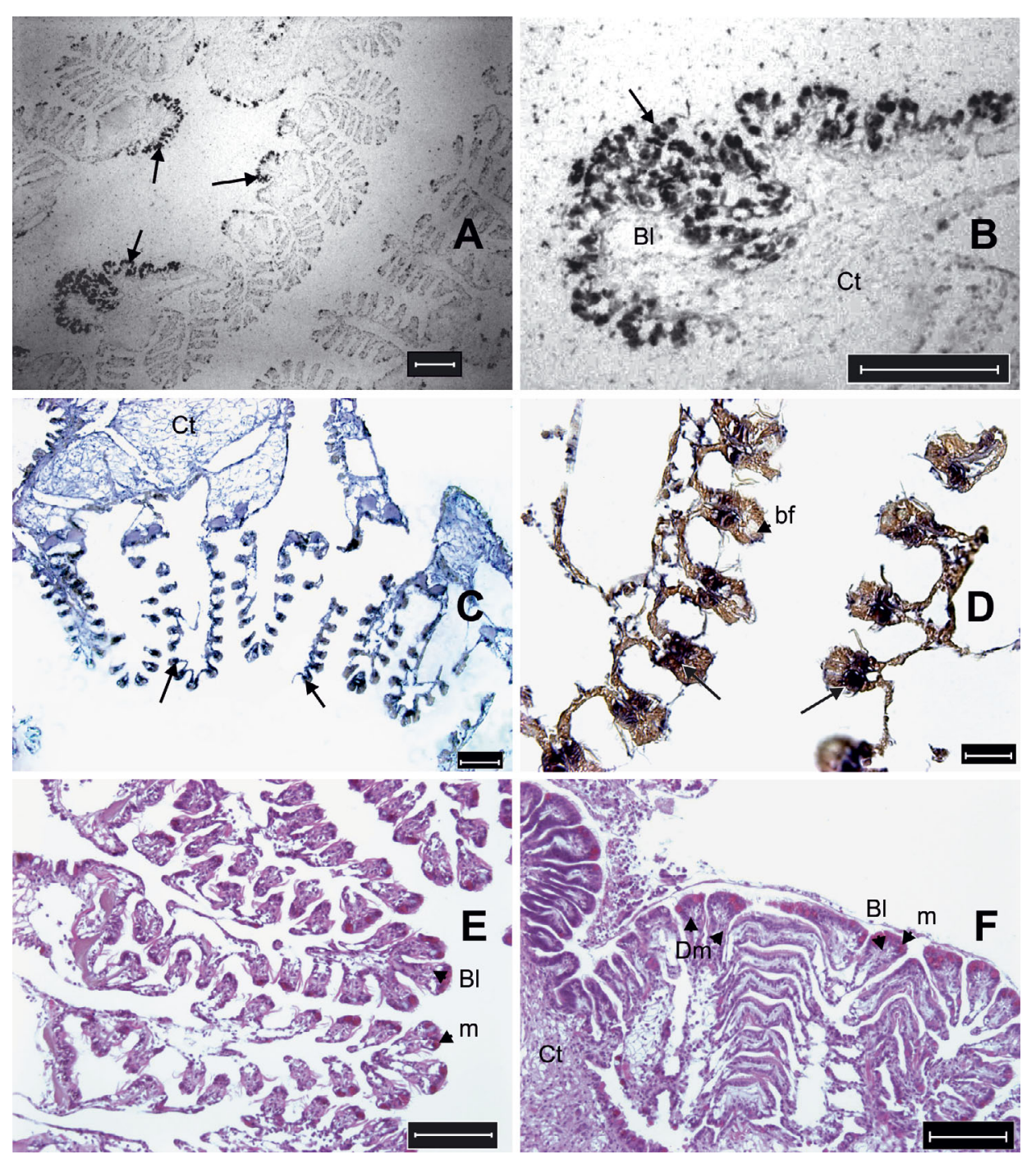

Fig. 2. Crassostrea gigas. Light microscopy images of gill tissues from an oyster cohabitated with white spot syndrome virus (WSSV)-infected Litopenaeus vannamei shrimp at $72 \mathrm{~h}$ that tested positive for WSSV by nested PCR. Histological tissue sections were examined either by (A-D) in situ hybridization (ISH) or (E,F) haematoxylin and eosin (H\&E) staining. (A,B) ISH signal (arrows) in filaments. (B,C) Absence of ISH signal from vesicular connective tissue and basal lamina. (D) Presence of ISH signal in inter-filament spaces. $(\mathrm{E}, \mathrm{F})$ No evidence of hypertrophied cell nuclei or WSSV inclusion bodies in vesicular connective tissue and basal lamina. Bf: branchial filament; $\mathrm{Ct}$ : vesicular connective tissue; m: mucocytes; Dm: demibranch of gill; Bl: basal lamina. Scale bars $=(A, B, C, E, F) 100 \mu \mathrm{m},(D) 10 \mu \mathrm{m}$ 
C. gigas is refractory to WSSV infection. The number of WSSV particles captured from water and accumulated in the gills and digestive glands of oysters was low and found to be harmless for shrimp in cohabitation trials. The finding that oysters can concentrate WSSV particles is not unexpected due to their ability to filter large volumes of water (FAO 2011). Their value to shrimp farmers as a sentinel in intake water canals was confirmed by WSSV being detected by nested PCR in some oysters $16 \mathrm{~d}$ prior to a WSD outbreak occurring in ponds. Such early warning of possible WSSV entry into farms via intake water will provide farmers and managers with the time needed to take appropriate actions to avoid an epizootic event or to harvest shrimp before mortalities occur. Durations between when WSSV is detected in sentinel oysters and when WSD occurs could depend on many factors including shrimp immune status and environmental parameters such as salinity and temperature being more or less conducive to disease (Jimenez et al. 2000). Whether C. gigas has the potential to serve as a mechanical carrier of WSSV, as reported for polychaete worms (Vijayan et al. 2005) that are capable of transmitting infection to shrimp when ingested, was not investigated.

Histology and in situ hybridization on gills of Crassostrea gigas showed WSSV to accumulate in the absence of infection. The virus was abundant in the filament surface of gills but there was no evidence of inclusion bodies or WSSV DNA in epithelial and connective cells, suggesting that they lack receptors needed for virus entry. These findings agree with recent reports showing that other bivalve molluscs such as the clam Meretrix lusoria are not susceptible to WSSV infection (Chang et al. 2011). The accumulation of virus particles in the absence of infection has been observed previously in molluscs exposed to certain human viruses, with oyster depuration treatments not eliminating them (Mortensen 1993, Lees 2000, Nappier et al. 2008).

The mechanisms by which potentially pathogenic agents are accumulated by and eliminated from bivalve molluscs can vary according to species and the type of microorganism (Chang et al. 2011). However, since water and/or particles in shrimp ponds can disperse WSSV (Esparza Leal et al. 2009) and given that virus particles can attach to microalgae and/or zooplankton and plankton constituents (Liu et al. 2007, Zhang et al. 2007, 2008), they could adhere to the branchial mucus in Crassostrea gigas by ionic bonding, as suggested by Di Girolamo et al. (1977). The virus would then travel to the digestive gland and attach to the digestive ducts via specific carbohydrate structures (Sobsey \& Jaykus 1991, Le Guyader et al. 2006). According to the mechanism described by Hay \& Scotti (1986), the fact that virus particles can adhere strongly to microalgae could prevent the oyster from eliminating these with pseudofeces when selecting its food. Future studies on C. gigas will be needed to determine the WSSV particle retention mechanisms.

The data reported here confirm that Crassostrea gigas oysters can accumulate WSSV particles in their gills and digestive glands though either direct filterfeeding or filter-feeding of plankton to which WSSV particles have attached. Moreover, as oysters are refractive to WSSV infection, they represent an ideal sentinel species for warning of the presence of WSSV in shrimp farm intake water.

Acknowledgements. This study is part of a Strategic Alliance and Network of Aquaculture Industry Innovation supported by CONACYT (Grant AERIS-2008-87684) and the 'Comités de Sanidad Acuícola' in Sinaloa (CESASIN), Sonora (COSAES), Nayarit (CESANAY) and Baja California Sur (CSABCS). We thank P. Monsalvo-Spencer, G. LaraAnguiano and M. Ramirez-Orozco for maintaining and collecting animals and I. Gomez-Pacheco, N. Gutierrez-Rivera, G. Hernandez-Garcia and C. Rodriguez-Jaramillo for assistance with PCR, histology and photo-editing.

\section{LITERATURE CITED}

Chang PS, Chen HC, Wang YC (1998) Detection of white spot syndrome associated baculovirus in experimentally infected wild shrimp, crabs and lobsters by in situ hybridization. Aquaculture 164:233-242

Chang YS, Chen TC, Liu WJ, Hwang JS, Kou GH, Lo CF (2011) Assessment of the roles of copepod Apocyclops royi and bivalve mollusk Meretrix lusoria in white spot syndrome virus transmission. Mar Biotechnol 13:909-917

> Chen LL, Lo CF, Chiu YL, Chang CF, Kou GH (2000) Natural and experimental infection of white spot syndrome virus (WSSV) in benthic larvae of mud crab Scylla serrata. Dis Aquat Org 40:157-161

> Chou HY, Huang CY, Lo CF, Kou GH (1998) Studies on transmission of white spot syndrome associated baculovirus (WSBV) in Penaeus monodon and P. japonicus via waterborne contact and oral ingestion. Aquaculture 164:263-276

Claisse D (1989) Chemical contamination of French coasts: the results of a ten years mussel watch. Mar Pollut Bull 20:523-528

Comisión Nacional de Acuacultura y Pesca (2009) Anuario Estadístico de Acuacultura y Pesca 2009. www. conapesca.sagarpa.gob.mx (accessed 24 May 2011)

Corsin F, Turnbull JF, Mohan CV, Hao NV, Morgan KL (2005) Pond-level risk factors for white spot disease outbreaks. In: Walker P, Lester R, Bondad-Reantaso MS (eds) Diseases in Asian aquaculture V. Fish Health Section, Asian Fisheries Society, Manila, p 75-92

Di Girolamo R, Liston J, Matches J (1977) Ionic bonding: the mechanism of viral uptake by shellfish mucus. Appl Environ Microbiol 33:19-25 
Escobedo-Bonilla CM, Wille M, Alday-Sanz V, Sorgeloos P, Pensaert MB, Nauwynck HJ (2005) In vivo titration of white spot syndrome virus (WSSV) in specific pathogenfree Litopenaeus vannamei by intramuscular and oral routes. Dis Aquat Org 66:163-170

Escobedo-Bonilla CM, Audoorn L, Wille M, Alday-Sanz V, Sorgeloos P, Pensaert MB, Nauwynck HJ (2006) Standardized white spot syndrome virus (WSSV) inoculation procedures for intramuscular or oral routes. Dis Aquat Org 68:181-188

Escobedo-Bonilla CM, Alday-Sanz V, Wille M, Sorgeloos P, Pensaert MB, Nauwynck HJ (2008) A review on the morphology, molecular characterization, morphogenesis and pathogenesis of white spot syndrome virus. J Fish Dis 31: $1-18$

Esparza-Leal HM, Escobedo-Bonilla CM, Casillas-Hernández R, Álvarez-Ruíz P and others (2009) Detection of white spot syndrome virus in filtered shrimp-farm water fractions and experimental evaluation of its infectivity in Penaeus (Litopenaeus vannamei). Aquaculture 292: $16-22$

FAO (2011) Cultured aquatic species information programme Crassostrea gigas. FAO, Rome. www.fao.org/ fishery/culturedspecies/Crassostrea_gigas/fr (accessed September 9, 2011)

- Hameed ASS, Balasubramanian G, Musthaq SS, Yoganandhan K (2003) Experimental infection of twenty species of Indian marine crabs with white spot syndrome virus (WSSV). Dis Aquat Org 57:157-161

Hay B, Scotti P (1986) Evidence for intracellular absorption of virus by the Pacific oyster Crassostrea gigas. NZ J Mar Freshw Res 20:655-659

> Huang CH, Zhang LR, Zhang JH, Xiao LC, Wu QJ, Chen DH, Li JKK (2001) Purification and characterization of white spot syndrome virus (WSSV) produced in an alternate host: crayfish Cambarus clarkii. Virus Res 76:115-125

> Jiménez R, Barniol R, De Barniol L, Machuca M, Romero X (2000) Viral-like particles associated with cuticular epithelium necrosis in cultured Litopenaeus vannamei (Decapoda: Crustacea) in Ecuador. Aquacult Res 31:519-528

- Kimura T, Yamano K, Nakano H, Momoyama K, Hiraoka M, Inouye K (1996) Detection of penaeid rod-shaped DNA virus (PRDV) by PCR. Fish Pathol 31:93-98

Kwan KHM, Chang HM, De Lafontaine Y (2003) Metal contamination in zebra mussels (Dreissena polymorpha) along the St Lawrence River. Environ Monit Assess 88: 193-219

Le Guyader FS, Loisy F, Atmar RL, Hutson AM and others (2006) Norwalk virus-specific binding to oyster digestive tissues. Emerg Infect Dis 12:931-936

> Le Roux F, Audemard C, Barnaud A, Berthe FCJ (1999) DNA probes as potential tools for the detection of Marteilia refringens. Mar Biotechnol 1:588-597

Lees D (2000) Viruses and bivalve shellfish. Int J Food Microbiol 59:81-116

Lightner DV (1996) A handbook of shrimp pathology and diagnostic procedures for diseases of cultured penaeid shrimp. World Aquaculture Society, Baton Rouge, LA

Liu B, Yu Z, Song X, Guan Y (2007) Studies on the transmission of WSSV (white spot syndrome virus) in juvenile Marsupenaeus japonicus via marine microalgae. J Invertebr Pathol 95:87-92

Luna LG (ed) (1968) Manual of histologic staining methods of the Armed Forces Institute of Pathology. McGraw-Hill, New York, NY
Miller WA, Atwill ER, Gardner IA, Miller MA and others (2005) Clams (Corbicula fluminea) as bioindicators of fecal contamination with Cryptosporidium and Giardia spp. in freshwater ecosystems in California. Int J Parasitol 35:673-684

Mortensen SH (1993) Passage of infectious pancreatic necrosis virus (IPNV) through invertebrates in an aquatic food chain. Dis Aquat Org 16:41-45

Nappier SP, Graczyk TK, Schwab KJ (2008) Bioaccumulation, retention, and depuration of enteric viruses by Crassostrea virginica and Crassostrea ariakensis oysters. Appl Environ Microbiol 74:6825-6831

Neira OP, Muñoz SN, Stanley VB, Gosh CM, Rosales LMJ (2010) Cryptosporidium parvum in wild gastropods as bioindicators of fecal contamination in terrestrial ecosystems. Rev Chilena Infectol 27:211-218

Peinado-Guevara LI, López-Meyer M (2006) Detailed monitoring of white spot syndrome virus (WSSV) in shrimp commercial ponds in Sinaloa, Mexico by nested PCR. Aquaculture 251:33-45

Rajendran KV, Vijayan KK, Santiago TC, Krol RM (1999) Experimental host range and histopathology of white spot syndrome virus (WSSV) infection in shrimp, prawns, crayfish and lobsters from India. J Fish Dis 22: 183-191

Reed LJ, Muench H (1938) A simple method of estimating fifty percent endpoints. Am J Hygiene 27:493-497

> Sánchez-Martínez JG, Aguirre-Guzmán G, Mejía-Ruíz H (2007) White spot syndrome virus in cultured shrimp: a review. Aquacult Res 38:1339-1354

Sobsey MS, Jaykus LA (1991) Human enteric viruses and depuration of bivalve mollusks. In: Otwell WS, Rodrick GE, Martin RE (eds) Molluscan shellfish depuration. CRC Press, Boca Raton, FL, p 71-114

Sritunyalucksana $\mathrm{K}$, Wannapapho W, Lo CF, Flegel TW (2006) PmRab7 is a VP28-binding protein involved in white spot syndrome virus infection in shrimp. J Virol 80: 10734-10742

Unzueta Bustamante ML, Silveira Cofficny R, Prieto AA, Aguirre Guzman G, Vázquez Juárez R (2004) Susceptibilidad de Litopenaeus schmitti y Cherax quadricarinatus al virus del síndrome de la mancha blanca (WSSV). Cienc Mar 30:537-545

Vazquez-Boucard C, Alvarez-Ruiz P, Escobedo-Fregoso C, Anguiano-Vega G, Duran-Avelar MJ, Serrano-Pinto V, Escobedo-Bonilla CM (2010) Detection of white spot syndrome virus (WSSV) in the Pacific oyster Crassostrea gigas. J Invertebr Pathol 104:245-247

Vijayan KK, Stalin Raj V, Balasubramanian CP, Alavandi SV, Thillai Sekhar V, Santiago TC (2005) Polychaete worms - a vector for white spot syndrome virus (WSSV). Dis Aquat Org 63:107-111

> Wu JL, Namikoshi A, Nishizawa T, Mushiake K, Teruya K, Muroga K (2001) Effects of shrimp density on transmission of penaeid acute viremia in Penaeus japonicus by cannibalism and the waterborne route. Dis Aquat Org 47:129-135

Zhang JS, Dong SL, Tian XL, Dong YW, Liu XY, Yan DC (2007) Virus-phytoplankton adhesion: a new WSSV transmission route to zooplankton. Acta Oceanol Sin 23: 109-115

Zhang JS, Dong SL, Dong YW, Tian XL, Hou CQ (2008) Bioassay evidence for the transmission of WSSV by the harpacticoid copepod Nitocra sp. J Invertebr Pathol 97: 33-39 